\title{
Penerapan Single Sign On dengan Google pada Website berbasis YII Framework
}

\author{
Application Single Sign On with Google the Website \\ Based on Yii Framework
}

\author{
Qurotul Aini $^{1}$, Untung Rahardja ${ }^{2}$, Romzi Syauqi Naufal ${ }^{3}$ \\ Dosen STMIK Raharja Jurusan Sistem Informasi ${ }^{1}$, Dosen STMIK Raharja Jurusan Sistem \\ Informasi $^{2}$, Mahasiswa STMIK Raharja Jurusan Sistem Komputer ${ }^{3}$ \\ e-mail: aini@ raharja.info ${ }^{1}$, untung@ raharja.info $^{2}$, romzi@ raharja.info ${ }^{3}$
}

\begin{abstract}
Abstrak
Perkembangan internet berkembang begitu pesat dan terus berinovasi dan menciptakan terobosan yang baru. Teknologi single sign on adalah teknologi yang diminati, terutama di jaringan yang sangat besar dan heterogen (dalam sistem operasi saat ini dan aplikasi yang digunakan oleh komputer berasal dari banyak vendor diminta untuk mengisi informasi itu sendiri ke setiap platform yang berbeda untuk diakses oleh pengguna). Dengan menggunakan SSO, pengguna hanya cukup berusaha untuk otentikasi hanya sekali untuk mendapatkan izin, akses ke seтиa layanan yang terdapat dalam jaringan. Aktifitas login yang sering menggunakan NIM (Nomer Induk Mahasiswa) dan password sebuah akun google yang berbeda - beda tergantung user itu melakukan settings. Kesulitan untuk login jika seorang pengguna login yang berbeda-beda untuk setiap sistem yang digunakan, karena seseorang harus dapat mengingat banyak username dan password yang juga keamanan harus dijaga dengan baik. Single Sign On ( SSO ) with google merupakan fasilitas yang memberikan kemudahan untuk user yang melakukan login ketika menjelajah di internet. User hanya perlu login satu kali saja agar menggunakan semua fasilitas yang ada di website yang berbasis YII Framework. Disimpulkan dengan SSO with google dalam system dapat mempermudah aktifitas satu kali Login dan menangani authentifikasi.
\end{abstract}

Kata kunci - Single Sign On ,Google, Login, Website dan YII Framework.

\begin{abstract}
The development of the internet developed so rapidly and continue to innovate and create a new breakthrough. Single sign on technology is a popular technology, especially in very large and heterogeneous networks (in the current operating system and applications used by computers coming from many vendors are required to fill in the information itself to each different platform for user access). By using SSO, users only attempt to authenticate only once for permission, access to all services contained in the network. Login activities that often use a NIM (Number Identity college student) and password a google account that is different different depending on the user's settings. Difficulty logging in if a different login user for each system is used, because one should be able to remember many usernames and passwords which also security must be kept well. Single Sign On (SSO) with google is a facility that provides convenience for users who login when surfing the internet. Users only need to login once to use all the facilities on the website based on YII Framework. Inferred with SSO with google in the system can simplify the one-time login activity and handle authentication.
\end{abstract}

Keywords - Single Sign On, Google, Login, Website and YII Framework. 


\section{PENDAHULUAN}

Perkembangan internet terus semakin pesat sehingga memungkinkan sebagian besar lembaga formal maupun non formal untuk terlibat di dalamnya. Beberapa prinsip sederhana yang dimiliki internet dan diminati oleh banyak user adalah mudah dan menyenangkan untuk digunakan bagi penggunanya, dengan demikian fungsi internet semakin multifungsi. Seiring dengan maraknya penggunaan internet sehingga melibatkan jumlah user dalam penggunaan internet semakin bertambah banyak. Namun dengan semakin banyaknya jumlah user, secara tidak langsung akan menyebabkan masalah baru baik dari sisi user itu sendiri maupun admin sebagai pengelola user. Permasalahan yang dihadapi user yaitu terdapat banyak user yang lupa dengan user account dan password yang dimilikinya karena harus mengingat semua username dan password untuk login ke setiap sistem yang berbeda - beda.

Tingkat keamanan user account semakin diperkuat. Permasalahan baru bagi admin, yaitu masalah sulitnya admin dalam mengelola user account. Selama beberapa waktu ini telah banyak dikembangkan berbagai cara untuk mempermudah pengelolaan dan meningkatkan keamanan user account, diantaranya dengan cara menerapkan pemanfaatan Centralized Cookiebased SSO (Single Sign On). Dalam rangka untuk meningkatkan efisiensi user, keamanan sistem informasi, dan produktivitas IT, maka ada beberapa cara untuk membangun sebuah sistem jaringan kedalam SSO (Single Sign On).

Server SSO sebenarnya tidak berbeda dengan aplikasi web pada umumnya, tugasnya hanya menangani request dan memberikan response terhadap client yang mengakses. Namun, kalau Server SSO 99\% tugasnya adalah menangani authentifikasi. SSO (Single Sign On) diterapkan dalam berbagai Website untuk mempermudah User Login. Website berbasis Yii Framework sangat mudah untuk diterapkan SSO (Single Sign On).

Single Sign On (Priyo Puji Nugroho, 2012) adalah sebuah mekanisme yang membuat user hanya perlu mengingat satu username dan password yang autentik untuk membuka beberapa layanan sekaligus. Dari dua pengertian tersebut yang dapat saya ambil bahwa single sign on system merupakan suatu mekanisme autentikasi untuk dapat mengakses keseluruhan sumber daya seperti beberapa situs atau layanan lainnya hanya dengan satu kali login saja. Sistem Single Sign On menghindari login ganda dengan cara mengidentifikasi subjek secara ketat dan memperkenankan informasi otentikasi untuk digunakan dalam sistem atau kelompok sistem yang terpercaya. Sistem SSO dapat meningkatkan kegunaan jaringan secara keseluruhan dan pada saat yang sama dapat memusatkan pengelolaan dari parameter sistem yang relevan. Pengguna layanan lebih menyukai sistem Single Sign On, namun pengelola layanan jaringan memiliki banyak tugas tambahan yang harus dilakukan, seperti perlunya perhatian ekstra untuk menjamin bukti-bukti otentikasi agar tidak tersebar dan tidak disadap pihak lain ketika melintasi jaringan. Adapun Penelitian yang sudah dilakukan banyak sekali mengenai penerapan single sign on, Pengembangan sistem penerapan single sign on ini melakukan lima tinjauan pustaka terhadap penelitian terdahulu untuk menjadi pedoman di dalam pengembangan ini, yaitu Penelitian yang dilakukan oleh Gilang Ramadhan, dari Universitas Bina Darma pada tahun 2012 dengan judul "Analis Teknologi Single Sign On (SSO) Dengan Penerapan Central Authentication Service (CAS) Pada Universitas Bina Darma" Penelitian ini menjelaskan mengenai bagaimana mengintegrasikan dan memberikan izin dalam mengakses beberapa aplikasi web secara terpusat pada system dengan menggunakan Analis Teknologi Single Sign On (SSO) [1]. Penelitian yang dilakukan oleh Amiudin, dari Universitas Muhammadiah Malang pada tahun 2014 dengan judul "Implementasi Single Sign On (SSO) Untuk mendukung Interaktifitas Aplikasi E-Commerce Menggunakan Protocol Oauth" Penelitian ini menjelaskan mengenai hal yang terkait dengan membangun aplikasi Single Sign On (SSO) dengan menggunakan SSO, pengguna dapat mengakses hanya dengan sekali untuk mendapatkan izin. Akses ke semua yang terdapat dalam jaringan [2]. Penelitian yang dilakukan oleh Ragil Widiharso, dari ITS (Institut Teknologi Sepuluh November) pada tahun 2009 dengan judul 
"Single Sign On Pada Learning Management System dan Internet System Protocol Television" Penelitian ini menjelaskan pemanfaatan teknologi lain untuk menunjang Learning Management System (LMS). Menggunakan sistem SSO untuk memberikan izin pengguna dalam mengakses beberapa aplikasi sekaligus tanpa harus login berulang kali. Metode SSO yang mendukung library dari client untuk PHP, bahasa pemograman yang digunakan untuk membuat web based IPTV [3]. Penelitian yang dilakukan oleh Budhi Irawan dari Institut Teknologi Telkom pada tahun 2012 dengan judul "Analisis Performansi Autentikasi Single Sign On Pada Web Menggunakan LDAP" Penelitian ini menjelaskan mengenai suatu kesulitan untuk login karena banyak aplikasi yang harus mengingat username dan password. Dengan menggunakan metode SSO user hanya perlu login hanya satu kali agar dapat menggunakan semua fasilitas yang ada di web utama. User tidak perlu mengingat account serta tidak perlu beberapa kali login. Dimana semua data user disimpan didalam LDAP. Tujuan dari penelitian ini untuk mendesain sistem (Single Sign On) yang bisa diterapkan pada berbagai aplikasi berbasis web dengan menggunakan metode ini. Dengan itu mempermudah user dalam melakukan login untuk dapat mengakses beberapa layanan yang ada [4]. Dari empat literature review yang ada, telah banyak penelitian sebelumnya bahwa penelitian mengenai sistem single sign on dalam aplikasi dan teknologi akan tetapi belum ada penelitian yang secara khusus membahas mengenai single sign on dengan Google pada Website yang berbasis YII Framework.

\section{METODE PENELITIAN}

Dalam merancang sebuah sistem hal penting yang diperlukan yaitu memperhatikan 6 hal untuk mengatasi berbagai masalah yang ada di atas maka didalam tahapan - tahapan penelitian diterapkan beberapa metode. Dalam penelitian ini metode penelitian yang diterapkan adalah Perumusan masalah, Perancangan Penelitian, Pengumpulan Data, Pengolahan Data, Penyajian Data, Analisis Data, Laporan Penelitian yang dimana dalam hal penerapan single sign on ini dapat memudahkan user atau pengguna dalam melakukan login tanpa perlu user mengingat Username dan password nya kembali, cukup dengan memasukkan alamat email yang sudah terdaftar sebelumnya pada website berbasis yii framework, pengguna dapat login dengan mudah dan juga cepat, dalam penelitian ini juga menggunakan metode autentikasi yang dimana peneliti harus mendapatkan client dan secret id pada console.developer.google.com agar website berbasis yii framework dapat diberikan izin untuk mengakses data user.

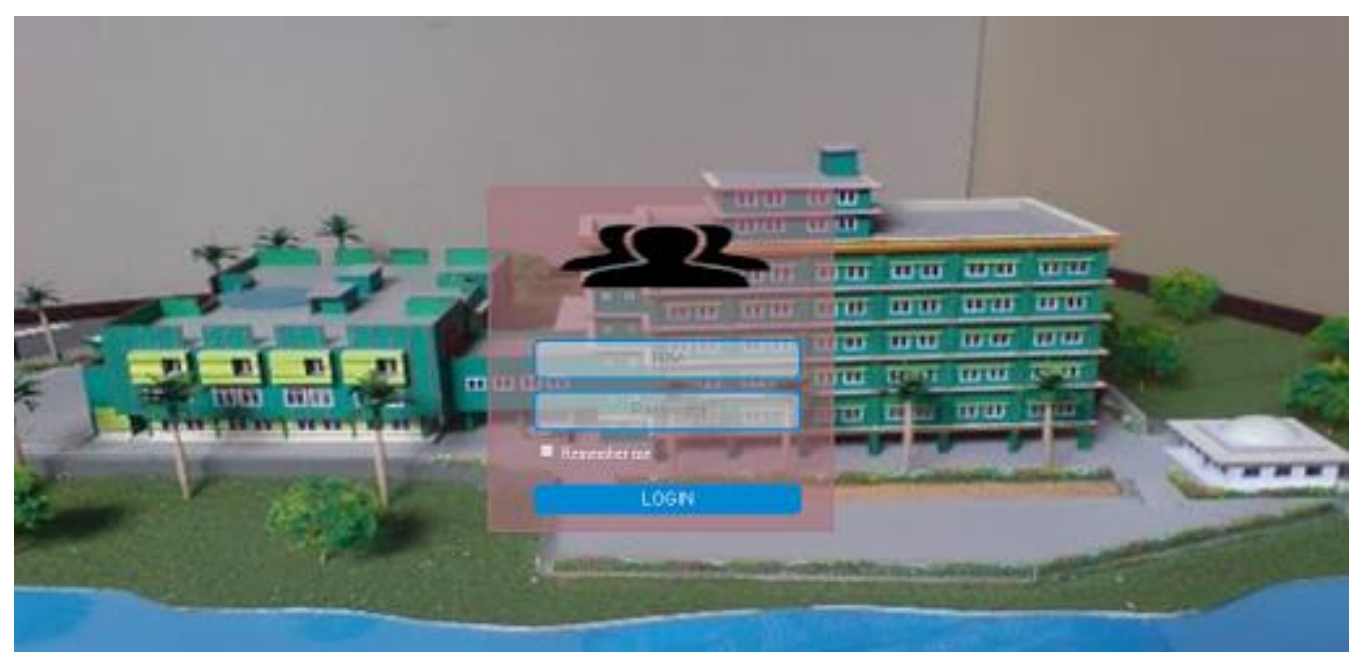

Gambar 1. Halaman Login Manual, input NIM dan Password 
Dalam salah satu contoh website yang tengah menggunakan metode penginputan NIM dan password dirasa sudah baik, namun mahasiswa atau user sering merasa kesulitan dalam proses login pada website tersebut yang mengakibatkan proses login menggunakan waktu lebih lama, dan lagi dalam satu waktu lebih dari satu mahasiswa yang melakukan proses login. Perancangan konsep Single Sign On pada website yii framework dalam bentuk prototype agar mudah dalam pemahaman saat diterapkan dalam website yii framework-Metode pengumpulan data yaitu penulis melaksanakan pengamatan pada sistem yang belum menggunakan metode single sign on pada Perguruan Tinggi Raharja, metode ini dilakukan untuk mengumpulkan data yang merupakan sumber informasi yang sangat berguna dan dapat membantu memberikan masukan kepada peneliti untuk menggunakan metode single sign on ini.

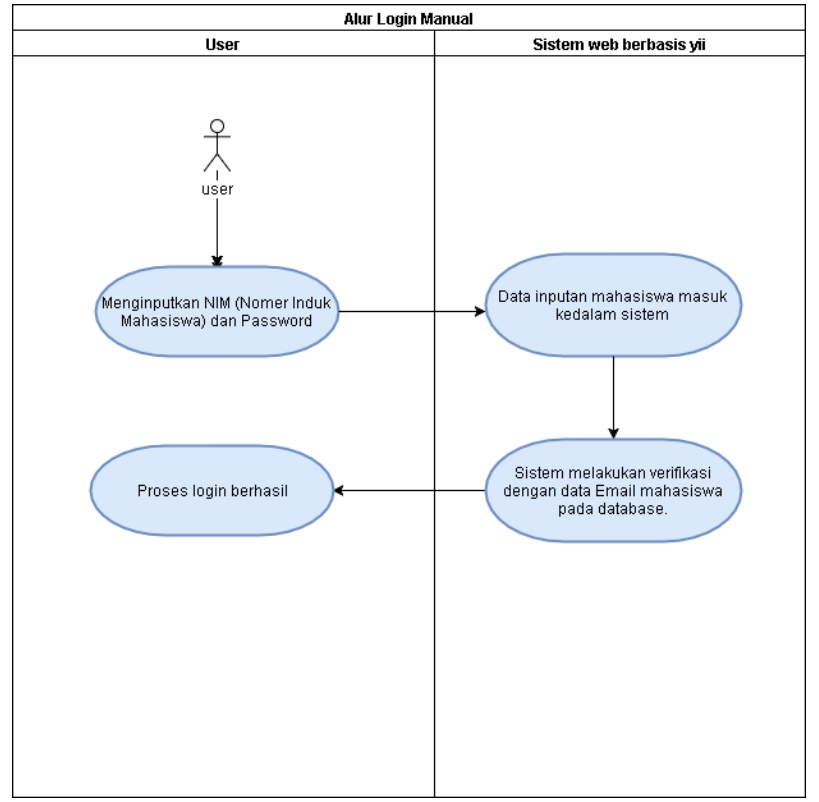

Gambar 2. Diagram Activity Permasalahan pada sistem yang berjalan

Sesuai dengan apa yang dilakukan selama melakukan observasi ini, dapat ditarik kesimpulan bahwa prosedur dalam mahasiswa melakukan login untuk dapat melakukan absensi masih adanya metode konvensional, yaitu mahasiswa masih perlu untuk mengingat password dan NIM (Nomer Induk Mahasiswa) agar dapat melakukan absensi bimbingan, yang seringkali mahasiswa lupa dengan password nya.

Metode ini dilaksanakan untuk mencari dan memperoleh analisis. Landasan teori yang mendukung, data-data, atau informasi sebagai referensi dalam melaksanakan perencanaan, percobaan, pembuatan dan penyusunan laporan, adapun penelitian sebelumnya dari berbagai sumber (literature) buku, dan beberapa jurnal untuk kebutuhan analisa serta perancangan yang terkait dengan penulisan tulisan ini. Berikut adalah beberapa Buku dan penelitian yang dijadikan sebagai sumber pustaka [1] Penelitian yang dilakukan oleh Aminudin (2014) yang berjudul "Implementasi Single Sign On (SSO) Untuk Mendukung Interaktivitas Aplikasi ECommerce Menggunakan Protocol Oauth". Penelitian ini membahas tentang teknologi Single Sign On yang merupakan teknologi yang diminati, terutama di jaringan yang sangat besar dan heterogen (dalam sistem operasi saat ini dan aplikasi yang digunakan oleh komputer berasal dari banyak vendor diminta untuk mengisi informasi itu sendiri ke setiap platform yang berbeda untuk diakses oleh pengguna). Dengan menggunakan SSO, pengguna hanya cukup berusaha untuk otentikasi hanya sekali untuk mendapatkan izin, akses ke semua layanan yang terdapat dalam jaringan. Penelitian yang dilakukan oleh Ragil Widiharso [2], dari ITS (Institut 
Teknologi Sepuluh November) pada tahun 2009 dengan judul "Analisa Implementasi Single Sign On Pada Learning Management System dan Internet System Protocol Television" Penelitian ini menjelaskan pemanfaatan teknologi lain untuk menunjang Learning Management System (LMS). Menggunakan sistem SSO untuk memberikan izin pengguna dalam mengakses beberapa aplikasi sekaligus tanpa harus login berulang kali. Metode SSO yang mendukung library dari client untuk PHP, bahas pemograman yang digunakan untuk membuat web based IPTV. [3] Penelitian yang dilakukan oleh Gilang Ramadhan, dari Universitas Bina Darma pada tahun 2012 dengan judul "Analis Teknologi Single Sign On (SSO) Dengan Penerapan Central Authentication Service (CAS) Pada Universitas Bina Darma" Penelitian ini menjelaskan mengenai bagaimana mengintegrasikan dan memberikan izin dalam mengakses beberapa aplikasi web secara terpusat pada system dengan menggunakan Analis Teknologi Single Sign On (SSO). [4] Indahni, Frisilia and Kunang, Yesi Novaria and Muzakir, Ari (2015), penelitian ini berjudul "Sistem Keamanan SSO pada Jalur Komunikasi Berbasis SAML Menggunakan Digital Signature" Single sign on merupakan teknologi yang mengizinkan pengguna untuk melakukan otentikasi pada beberapa aplikasi web hanya menggunakan satu username dan satu password. Pengguna cukup melakukan login sekali agar bisa mengakses beberapa aplikasi web yang terintegrasi. Single sign on menyediakan fasilitas Security Assertion Markup Language (SAML) sebagai portal penghubung antara pengguna dan aplikasi web. Dengan menggunakan beberapa aplikasi web yaitu moodle dan wordpress. SSO SAML menggunakan digital signature sebagai sistem keamanan antar server dengan menggunakan sertifikat SP, sertifikat Idp dan sertifikat CAS. Digital signature memiliki fungsi sebagai penanda pada data yang memastikan bahwa data tersebut adalah data yang sebenarnya (tidak ada yang berubah) dengan menggunakan algoritma RSA. [5] Penelitian yang dilakukan oleh Manisha Bhardwaj, Sarbjeet Singh dan Makhan Singh pada tahun 2011 penelitian ini berjudul "Implementation Of Single Sign-On And Delegation Mechanisms In Alchemi.Net Based Grid Computing Framework". Penelitian ini dilatar belakangi setelah menganalisa rinci kinerja Alchemi, telah mengidentifikasi bahwa Alchemi Berbasis. NET Grid Computing Framework tidak mendukung mekanisme seperti single sign-on, sehingga diinginkan untuk menambahkan mekanisme ini untuk meningkatkan kegunaan dan penerapannya. Single sign-on (SSO) adalah fitur yang diinginkan dari komputasi grid, meskipun terdapat beberapa cara untuk menerapkan single signon dan delegasi, namun dalam penelitian ini telah diimplementasi pada Alchemi.Net berdasarkan kerangka kerja komputasi grid melalui X.509 sertifikat proxy. Kemudian saat ini telah diterapkan single sign-on dan delegasi mekanisme untuk Alchemi.Netbased dengan memanfaatkan X.509 sertifikat proxy. Dalam implementasi ini komunikasi telah dibentuk antara dua host. Kemudian host yang bertindak sebagai klien telah di konfirmasi oleh tuan rumah yang bertindak sebagai server. Setelah di autentifikasi, klien diizinkan untuk mengakses berbagai aplikasi yang disediakan oleh Alchemi. Netbased framework komputerisasi grid dengan single sign-on dan hak delegasi penuh.

Dari 5 (Lima) studi pustaka yang ada, telah banyak penelitian mengenai pemanfaatan metode SSO (Single Sign On) dengan metode itu mempermudah user dalam melakukan login agar dapat melakukan absensi pada layanan yang di website berbasis yii.

\section{HASIL DAN PEMBAHASAN}

\subsection{Analisa Permasalahan}

Dalam salah satu contoh website yang masih menggunakan metode penginputan username dan password dirasa sudah baik, namun mahasiswa atau user sering merasa kesulitan dalam mengakses website tersebut yang mengakibatkan pembuatan QR Code menggunakan waktu lebih untuk proses login saja, dan lagi dalam satu waktu ada lebih dari satu mahasiswa yang ingin login. 


\subsection{Pemecahan Permasalahan}

Pada tahapan permasalahan yang sering terjadi pada website yii framework terdapat lebih dari satu hambatan dalam proses penginputan user id dan password pada saat login, maka dari itu untuk memperbaiki hambatan yang terjadi salah satunya user harus menghafal user id dan password, maka penyelesaian masalahnya yaitu dengan menggunakan metode single sign on agar user atau mahasiswa dapat lancar dalam proses login. Proses login menggunakan metode Single Sign On (SSO) yang dimana user perlu mendaftar kan dirinya kepada admin website agar data email terdata pada database user, dan juga agar user dapat melakukan sign in pada website yii

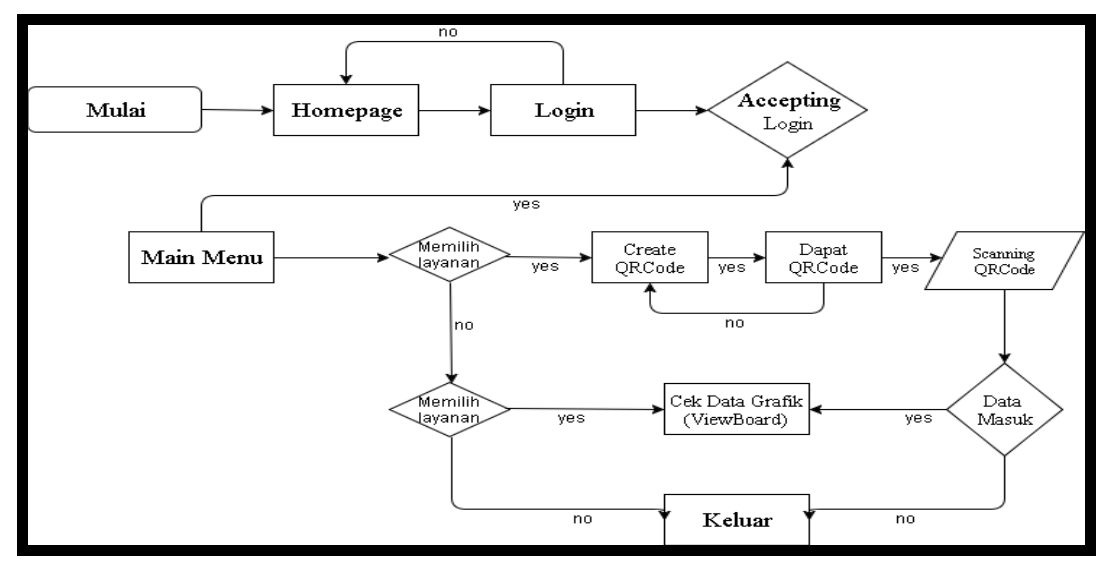

Gambar 3. Diagram alur proses keseluruhan website

Dapat diketahui sebelum masuk kedalam menu utama, user diwajibkan login terlebih dahulu. Setelah user sukses melalui proses login, apabila user tersebut baru, user dapat mendaftarkan dirinya kepada admin, setelah user baru dapat melakukan seleksi layanan yang tersedia pada menu utama website. Proses berjalannya login pada website yii, dimana tahapan awal user masuk halaman web portal yii, kemudian user login menggunakan akun Google. Setelah itu di autentikasi. Bila berhasil, user masuk ke halaman utama, bila tidak kembali ke halaman login.

\subsection{Proses Login}

Proses login menggunakan metode Single Sign On kali ini dapat mempermudah mahasiswa untuk melakukan login pada website khususnya website yang menggunakan framework yii, dimana prosesnya yaitu:

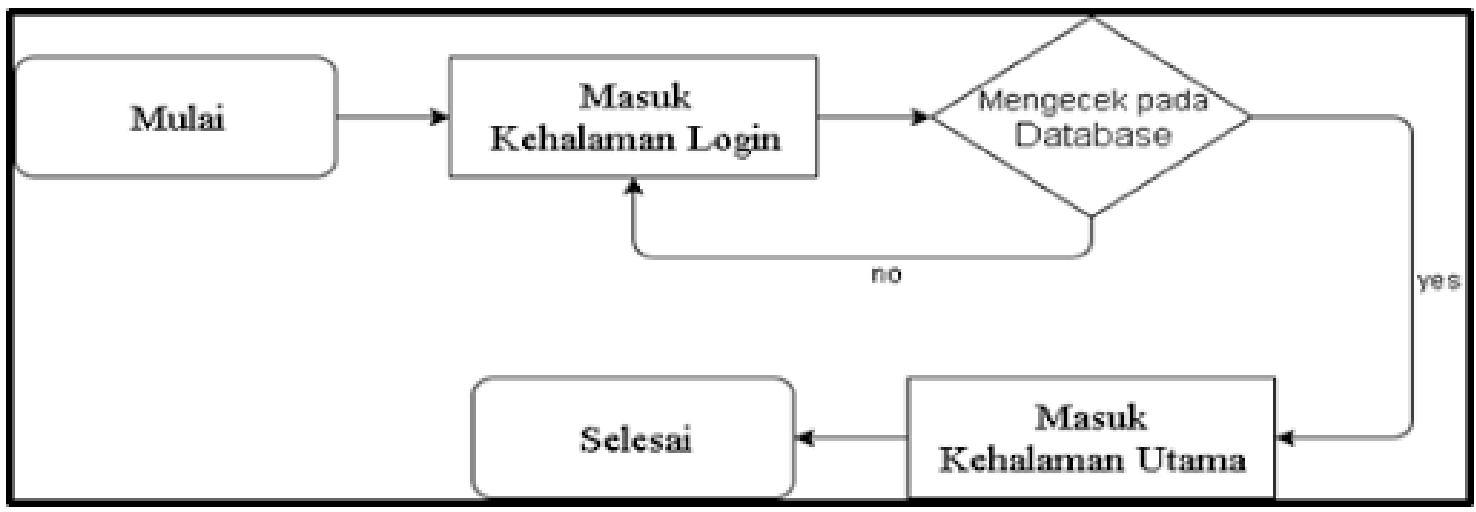

Gambar 4. Proses login SSO (Single Sign On) pada website yii 
Mahasiswa yang semula menginputkan NIM (Nomer Induk Mahasiswa) dan password dalam proses login, saat ini mahasiswa tidak lagi menginputkan NIM dan password melainkan mahasiswa yang sudah memiliki akun email terdaftar, maka dengan email tersebut mahasiswa dengan mudah dan efisien dapat melakukan proses login.

3.3 Listing Program

A. Tambahkan pada Composer JSON, Extension Authclient

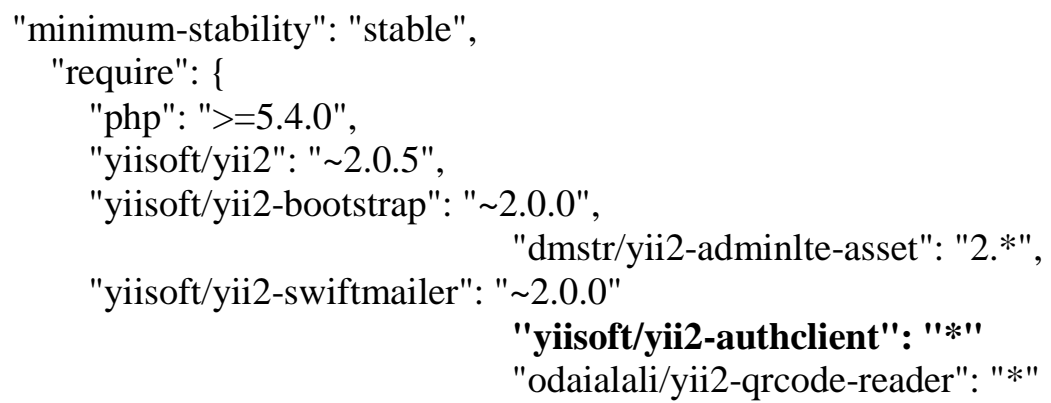

Dalam penambahan extension menjelaskan konfigurasi pada composer di website yii framework yang dimana proses konfigurasi menggunakan yii2-authclient pada file composer, dalam penambahan extension yii2-authclient agar dapat menjalankan menu Single Sign On (SSO).

B. Lihat folder config/web tambahkan Script dibawah ini

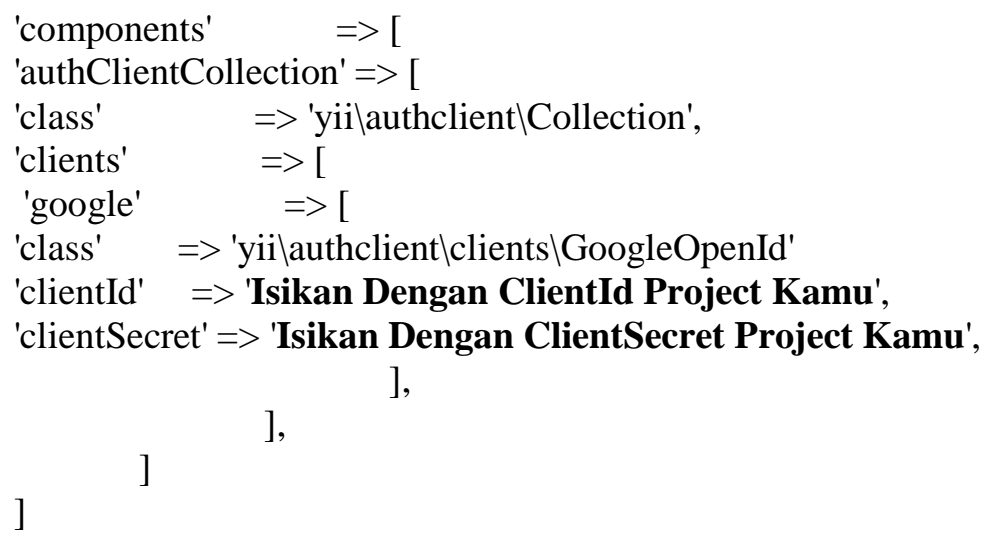

Dalam konfigurasi lanjutan ditambahkan script seperti diatas untuk dapat melakukan proses sign in pada website yii framework.

C. Dapatkan Client Secret dan Client ID pada console.developers.google.com 
Penerapan Single Sign On dengan Google ...

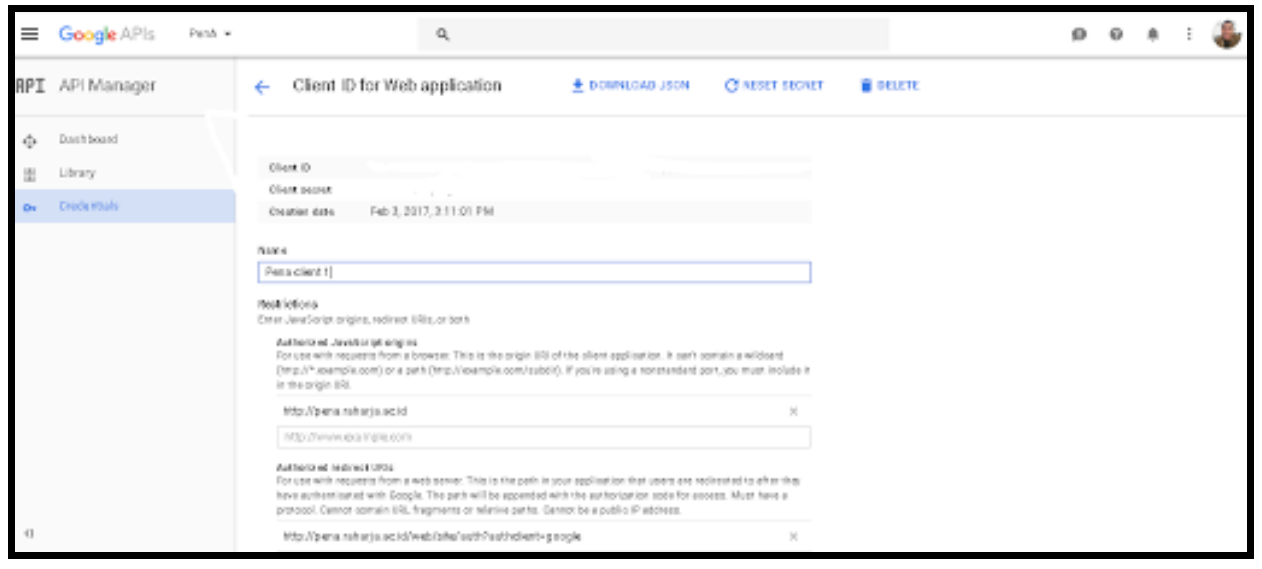

Gambar 5. Proses pembuatan Client dan Secret ID

Dalam proses mendapatkan client dan secret id dapat dilakukan pembuatan pada console.developer.google.com yang dimana client dan secret id berperan penting untuk menjalankan proses single sign on.

D. Konfigurasi pada Config Web Yii

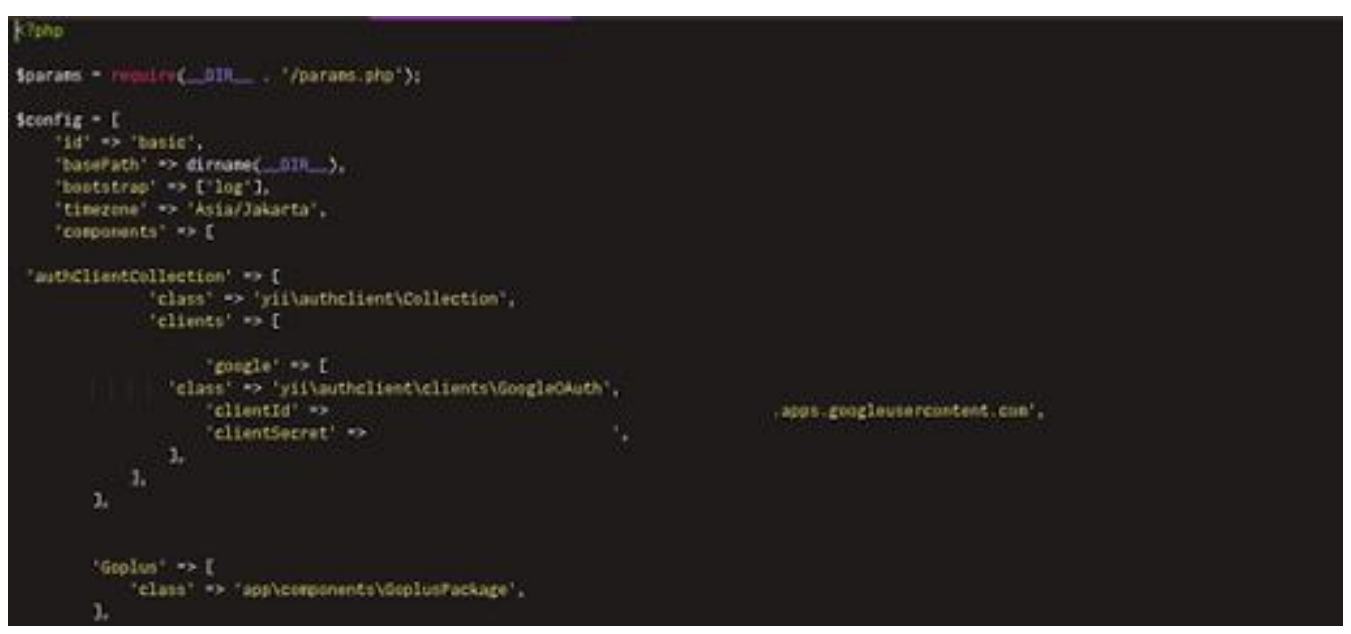

Gambar 6. Konfigurasi web yii

Pada konfigurasi web ini merupakan proses input Client ID dan Client Secret ID, yang sudah didapatkan pada saat proses pembuatan di console.developers.google.com dalam penginputan dilakukan dengan teliti apabila ada yang salah diantara Client ID atau Client Secret ID maka proses autentikasi tidak dapat berjalan dengan semestinya.

E. Tampilan SSO (Single Sign On) pada Website yii 


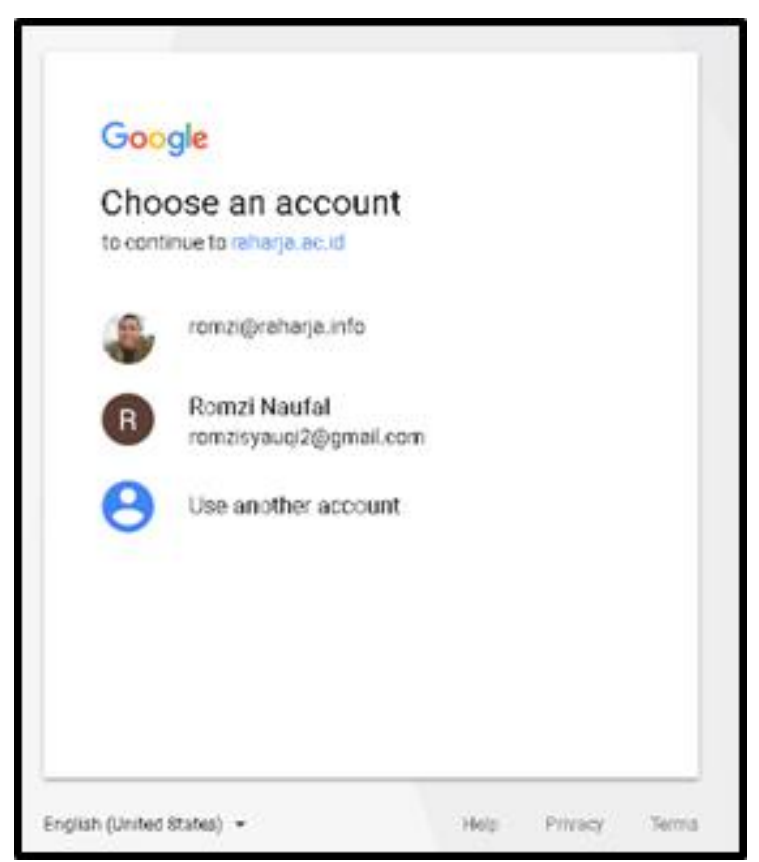

Gambar 7. Proses autentikasi Email

Pada proses Single Sign On mahasiswa dapat menseleksi akun mana yang sudah didaftarkan sebelumnya, apabila akun tidak didaftarkan maka system tidak akan menerima proses autentikasi, maka dari itu mahasiswa dianjurkan untuk memilih akun mana yang sudah didaftarkan.

F.Persiapan database user

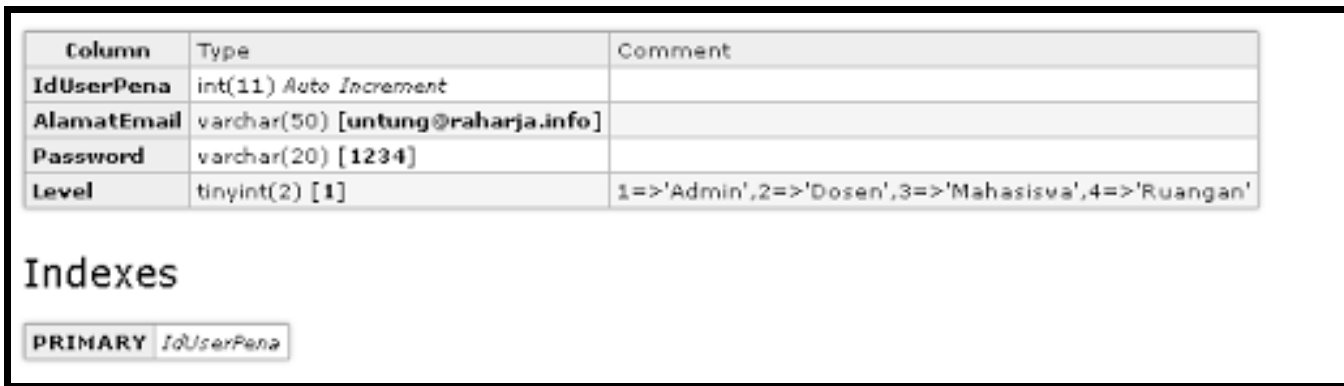

Gambar 8. Proses pembuatan database

Dalam proses autentikasi dengan database user, maka dibuat database untuk dapat memproses autentikasi user sign in mahasiswa. Pada database user terdiri dari Email, Nomer Induk Mahasiswa (NIM) dan Level, dalam proses autentikasi diperlukan pengecekan terhadap database user dan juga pada field level disini berguna mengidentifikasi setiap user yang login, dan juga berguna untuk membuatkan menu pada setiap levelnya.

G. Proses cek pada database user 
Penerapan Single Sign On dengan Google ...

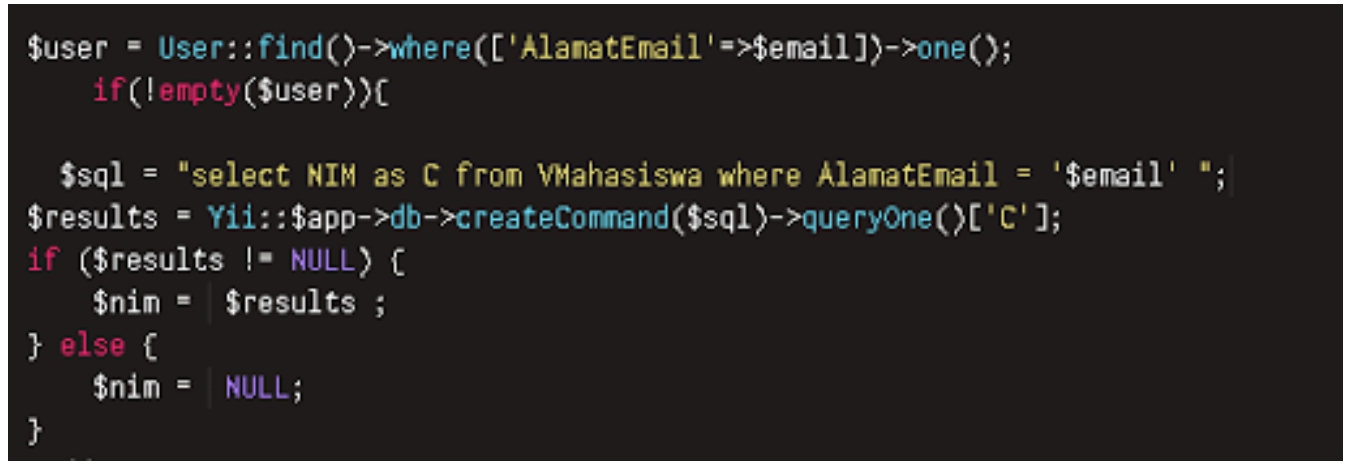

Gambar 9. Proses pengecekan data user

Pada proses pengecekan data user pada database user dimana proses pengecekannya dilakukan pada database user dikhususkan pencarian berdasarkan primary key yaitu alamat email, dengan alamat email ini dapat dijadikan parameter untuk proses login dikarenakan data yang diterima oleh website yii ialah berupa string alamat email, oleh karena hal itu proses hanya dikhususkan pada field alamat email saja.

3.4 Implementasi

\section{bSEnS:}

Home Information in PENA- Penilaian Absensi

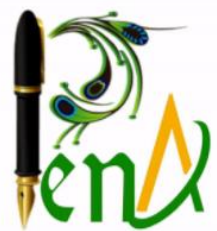

PENA - Penilaian Absensi adalah Pelayanan Absensi Online untuk kehadiran Dosen dan Mahasiswa pada perkuliahar.

PENA - Penilaian Absensi dapat memberikan pelayanan Absensi Online dan memberikan informasi Kehadiran Dosen dan Mahasiswa secara Real dalam perkuliahan.

PENA - Penilaian Absensi adalah sebuah Sistem Penilaian Kehadiran Absensi secara Online yang bertujuan untuk meningkatkan pelayanan pada Perguruan Tinggi Raharja .

PENA - Penilaian Absensi dirancang sangat user friendly sehingga memudahkan user saat mengakses PENA (Penilaian Absensi)

Dengan adanya PFNA - Penilaian Absensi, Memonitoring Kinerja Dosen dan Kualitas Mahasiswa dalam Absensi diperkuliahan dengan mudah juga dengan mudah mendapatkan hasil rekapan kualitas dosen pengajar.

Gambar 10. Tampilan Home website

Gambar 4 merupakan halaman login website yii framework dalam website tersebut proses login menggunakan metode single sign on melalui akun email user. 


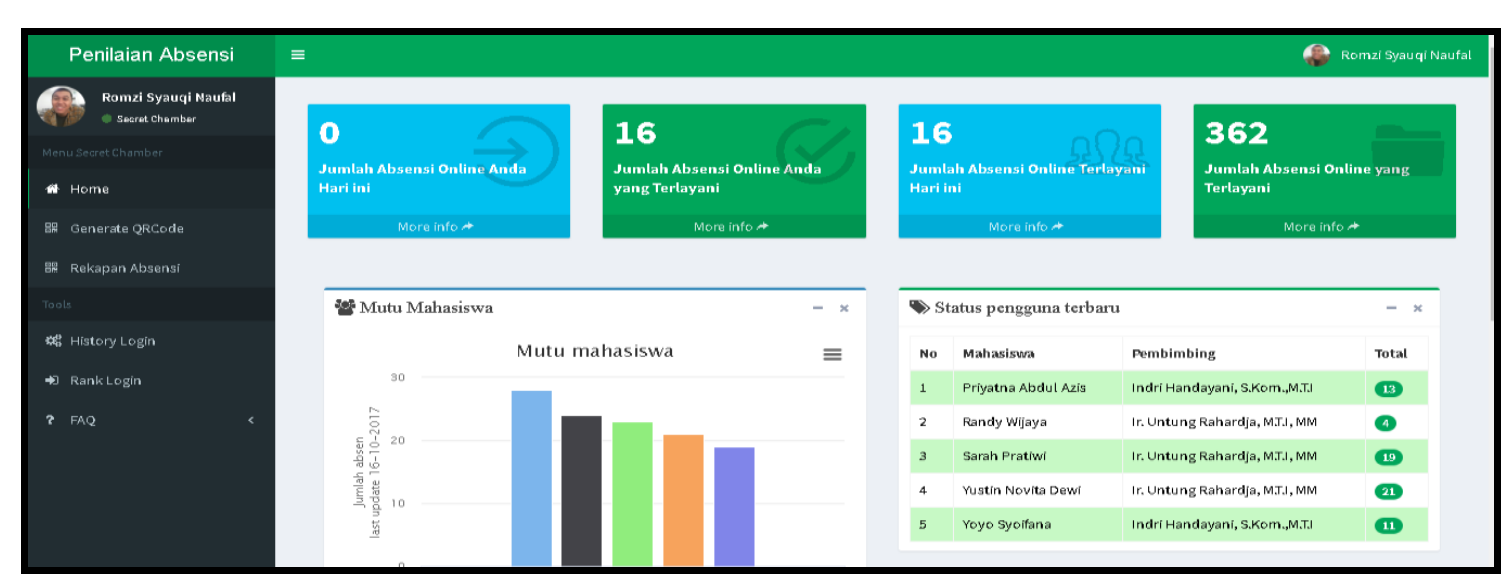

Gambar 11. Tampilan setelah login pada website yii framework

Pada gambar 5 merupakan tampilan user pada website yii setelah login, dalam hal ini website yang digunakan untuk media absensi mahasiswa bimbingan.

\section{KESIMPULAN}

Pada tahapan penerapan dan pengimplementasian metode Single Sign On (SSO) pada website yang menggunakan yii framework dimana pengguna web service berbasis yii framework terbantu dengan diimplementasikan Single Sign On bisa mempermudah mahasiswa karena tidak perlu menggunakan banyak account. Seperti contoh user adalah mahasiswa Perguruan Tinggi Raharja merasakan metode Single Sign On (SSO) ini bermanfaat mahasiswa karena mahasiswa tidak lagi direpotkan mengingat user id dan password kembali Dengan adanya single sign on ini lebih efisien dalam proses sign in pada website yii framework.

\section{SARAN}

Untuk pengembangan selanjutnya, beberapa saran yang dapat diberikan yaitu untuk menambahkan layanan lain seperti single sign menggunakan linked in, facebook, twitter dan media sosial lainnya dalam proses sign in pada website yii framework yang dapat dikembangkan untuk keperluan instant messaging dalam proses sign in yang lebih efisien menggunakan metode single sign on, dan bisa dikembangkan metode single sign on tidak hanya website yii framework, akan tetapi dapat digunakan pada website laravel ataupun codeigniter.

\section{UCAPAN TERIMA KASIH}

Pada kesempatan ini penulis mengucapkan terimakasih pada Perguruan Tinggi Raharja yang telah membantu penulis dalam mendukung secara finansial terhadap penulisan ini

\section{DAFTAR PUSTAKA}

[1]. Ramadhan, Galih. 2012. Analisis Teknologi Single Sign On (SSO) Dengan Penerapan Central Authentication Service (CAS) Pada Universitas Bina Darma. 2012. Universitas Bina Darma

[2]. Amiudin. 2014. Implementasi Single Sign On (SSO) Untuk Mendukung Interaktifitas Aplikasi E- Commerce menggunakan Protocol Oauth. Universitas Muhammadiah Malang. 
[3]. Widiharso, Ragil.Analisa 2012. Implementasi Single Sign On Pada Learning Management Sistem dan Internet Protocol Television Pada Institut Teknologi Sepuluh Nopember

[4]. Hilmi, Futuh. 2012. Analisis Performansi Autentikasi Single Sign On pada Web menggunakan LDAP pada Universitas Telkom Bandung

[5]. Warsito, A. B., Yusup, M., dan Makaram, I. (2015). Perancangan SIS+ Menggunakan Metode Yii Framework Pada Perguruan Tinggi Raharja. CCIT Journal Vol.8 No.2 Januari 2015 ISSN : 1978 - 8282.

[6]. Rahayu, S., Yusup, M., dan Dewi, S. P. Perancangan Aplikasi Absensi Peserta Bimbingan Belajar Berbasis Web Dengan Menggunakan Framework Yii. CCIT Journal Vol.9 No.1 - September 2015 ISSN : 1978 -8282.

[ 7]. Japerson Hutahaean. 2014. "Konsep Sistem Informasi". Yogyakarta : Deepublish.

[8]. Warsito.Ary Budi. Muhamad Yusup. Yulianto. 2014. Kajian YII Framework_Dalam Mengembangkan Website Perguruan Tinggi Jurnal CCIT STMIK Raharja Tangerang Vol 7 No 1 Mei 2014.

[9]. Irawan, Budhi. 2012. Analisis Performansi Autentikasi Single Sign On Pada Web Menggunakan LDAP. Institut Teknologi Telkom 